\title{
Effect of various extracts of Tabernaemontana divaricata on haloperidol induced catalepsy in rats
}

\author{
${ }^{*}$ Chanchal N. Raj ${ }^{1}$ A. Balasubramaniam², Sayyed Nadeem² \\ ${ }^{1}$ Department of Pharmacy, Karpagam University, Coimbatore, Tamilnadu, - 641021, India \\ ${ }^{2}$ Technocrats Institute of Technology-Pharmacy, Bhopal, M.P.-462021, India
}

\begin{abstract}
Parkinson's disease (PD) is one of the neurodegenerative diseases with selective loss of dopamine neurons of the substantia nigra pars compacta. In the present study, anti-cataleptic activity of Tabernaemontana divaricata leaves extracts viz. aqueous and ethanolic at different doses (50, 100 and $150 \mathrm{mg} / \mathrm{kg}$ i.p.) were studied using haloperidol $(1 \mathrm{mg} / \mathrm{kg}$, i.p.) induced catalepsy in rats which is a useful animal model for screening drugs for Parkinson's disease. Both the extracts were found to reduce catalepsy significantly $(\mathrm{P}<0.001)$ as compared to the haloperidol treated rats showing greater effect at $150 \mathrm{mg} / \mathrm{kg}$ i.p. dose. Thus the present study reveals the anticataleptic activity of Tabernaemontana divaricata evaluating the traditional folklore medicinal use of the plant.
\end{abstract}

Key Words: Tabernaemontana divaricata, Parkinson's disease (PD), catalepsy, haloperidol, bar test.

\section{INTRODUCTION}

Neurological disorders include brain injuries, neuroinfections, multiple sclerosis, Parkinson's disease, anxiety, depression, catalepsy etc. Among these anxiety and depression are the most common neurological disorders affecting up to one billion people worldwide as reported by World Health Organization (WHO) (Antony et al., 2010).

Parkinson's disease (PD) is one of the neurodegenerative diseases with selective loss of dopamine neurons (DA) of the substantia nigra pars compacta (SNc). However, the events which trigger and mediate the loss of nigral DA neurons still remain unclear. Neurolepticinduced catalepsy has been widely used as an animal model for screening antiparkinson drugs (Sanberg et al., 1988). The blockade of DA transmission produces catalepsy (Sanberg, 1980; Marie-Louise et al., 2001) in rats and extrapyramidal side effects in humans (Farde et al., 1992) which has been evident in several studies.

Catalepsy is a condition in which the animal retains the imposed posture for long time before retrieval of the normal posture. Catalepsy is a sign of extrapyramidal effect of drugs. Haloperidol is widely and commonly prescribed typical anti-psychotic drug for the treatment of schizophrenia and other effective disorders (Seeman et al., 1996; Kulkarni and Naidu, 2001) and can be used to induce catalepsy in animals.

It has been proposed that haloperidol induced oxidative stress causes due to generation of free radical catecholamine metabolism by monoamine oxidases (MAOs) (Mahdik and Mukherjee, 1996). Significant oxidative stress observed in the brain regions of animal with acute (Shivakumar and Ravindranath, 1992) and chronic (Shivakumar and Ravindranath, 1993) administration of haloperidol which is been demonstrated by loss of the nonprotein thiol anti-oxidant glutathione (GSH) and

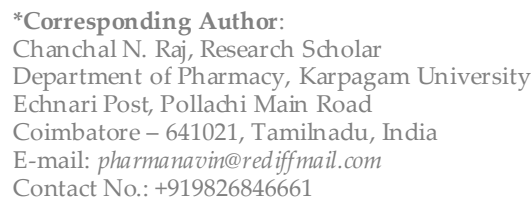

by the increase of the lipid peroxidation product, malonaldehyde. The pathophysiology of catalepsy still remains unclear. Theories implicating central cholinergic dysfunction, - $\gamma$-amino butyric acid (GABA) deficiency (Somani et al., 1999), oxidative stress (Kedar, 2003) and 5 hydroxy tryptamine (5-HT) (Silva et al., 1995) dysfunction have been proposed. Haloperidol is a dopamine D2 receptor antagonist that reduces dopaminergic transmission in basal ganglion thus producing a state of catalepsy in animals (Seeman et al., 1996) Tabernaemomntana divaricata L (Family:Apocynaceae) commonly called as Chandni in Hindi and crape jasmine in English, found in the drv regions of India, Sri Lanka and Bangladesh. Two tvpes of Crape Jasmine are available, one tvpe has a single blossom and the other has a clustered blossom. Both tvpes have a white-colored flower. Height of the plant is generallv 5 to $6 \mathrm{ft}$. The leaves are large, deep green in colour with shinv upper surface, about 6 inches in length and 2 inches in width. Small clusters of waxv blossoms grow on the stem tips (Van Beek et al., 1984; Leeuwenberg, 1991).

The beneficial properties of $T$. divaricata are antiinfection, anti-tumor action and analgesia. Enhancing the cholinergic function mav be therapeutically beneficial for manv neurodegenerative diseases, specificallv myasthenia gravis and Alzheimer's disease (Van Beek et al., 1984). Therapeutically active constituents from $T$. divaricata include alkaloids, terpenoids, steroids, flavonoids, tannins, phenyl propanoids, phenolic acids etc.

\section{MATERIALS AND METHODS}

\section{Plant material}

The leaves of Tabernaemontana divaricata (TD) were collected in January, 2010, from Bhopal, M.P., India. The plant was identified and authenticated by Dr. D. V. Amla Deputy Director, National Botanical Research Institute, Lucknow, India, and a voucher specimen no Tit/NBRI/CIF/141/2009 was deposited in Department of Pharmacognosy and Phytochemistry, TIT-Pharmacy, Bhopal. 
Table 1: Comparative anticataleptic activity of various extracts of Tabernaemontana divaricata with the standard drug (L-Dopa).

\begin{tabular}{|c|c|c|c|c|c|c|c|c|c|}
\hline \multirow{2}{*}{ Group } & \multirow{2}{*}{ Treatment } & \multirow{2}{*}{ Dose } & \multicolumn{7}{|c|}{ Time in Minutes (Mean Catalepsy Time) } \\
\hline & & & $0 \mathrm{~min}$ & $15 \mathrm{~min}$ & 30 Min & $45 \mathrm{Min}$ & 60 Min & 75 Min & $90 \mathrm{~min}$ \\
\hline Group-I & Haloperidol & $\begin{array}{c}1 \mathrm{mg} / \mathrm{kg}, \\
\text { i.p }\end{array}$ & $0.0 \pm 0.0$ & $0.64 \pm 0.16$ & $1.71 \pm 0.21$ & $2.33 \pm 0.29$ & $3.20 \pm 0.59$ & $4.02 \pm 0.63$ & $4.59 \pm 0.59$ \\
\hline Group-II & $\begin{array}{c}\text { Haloperidol + } \\
\text { L-Dopa }\end{array}$ & $\begin{array}{c}30 \mathrm{mg} / \mathrm{kg}, \\
\text { i.p }\end{array}$ & $0.0 \pm 0.0 \mathrm{~ns}$ & $0.0 \pm 0.0^{* * *}$ & $0.0 \pm 0.0^{* * *}$ & $0.0 \pm 0.0^{* * *}$ & $0.05 \pm 0.08$ *** & $0.10 \pm 0.08^{* * *}$ & $0.23 \pm 0.04^{* * * *}$ \\
\hline Group-III & $\begin{array}{c}\text { Haloperidol + } \\
\text { aqueous }\end{array}$ & $\begin{array}{c}50 \mathrm{mg} / \mathrm{kg}, \\
\text { i.p }\end{array}$ & $0.0 \pm 0.0 \mathrm{~ns}$ & $0.55 \pm 0.10 \mathrm{~ns}$ & $1.57 \pm 0.10 \mathrm{~ns}$ & $2.20 \pm 0.50 \mathrm{~ns}$ & $2.77 \pm 0.42 \mathrm{~ns}$ & $2.84 \pm 0.44^{*}$ & $3.04 \pm 0.20^{* * * *}$ \\
\hline Group-IV & extract & $\begin{array}{c}100 \mathrm{mg} / \mathrm{kg}, \\
\text { i.p }\end{array}$ & $0.0 \pm 0.0 \mathrm{~ns}$ & $0.46 \pm 0.14 \mathrm{~ns}$ & $1.50 \pm 0.15 \mathrm{~ns}$ & $2.16 \pm 0.59 \mathrm{~ns}$ & $2.52 \pm 0.60 \mathrm{~ns}$ & $2.73 \pm 0.47^{* *}$ & $2.83 \pm 0.36^{* * *}$ \\
\hline Group-V & & $\begin{array}{c}150 \mathrm{mg} / \mathrm{kg} \text {, } \\
\text { i.p }\end{array}$ & $0.0 \pm 0.0 \mathrm{~ns}$ & $0.42 \pm 0.14 \mathrm{~ns}$ & $1.35 \pm 0.29 \mathrm{~ns}$ & $1.47 \pm 0.27 * *$ & $1.75 \pm 0.61 * * *$ & $1.73 \pm 0.60^{* * *}$ & $1.99 \pm 0.53^{* * *}$ \\
\hline Group-VI & $\begin{array}{c}\text { Haloperidol + } \\
\text { ethanolic extract }\end{array}$ & $\begin{array}{c}50 \mathrm{mg} / \mathrm{kg}, \\
\text { i.p }\end{array}$ & $0.0 \pm 0.0 \mathrm{~ns}$ & $0.40 \pm 0.19 \mathrm{~ns}$ & $1.54 \pm 0.31 \mathrm{~ns}$ & $1.31 \pm 0.31^{* * *}$ & $1.78 \pm 0.63^{* * * *}$ & $1.84 \pm 0.55^{* * *}$ & $1.99 \pm 0.54^{* * * *}$ \\
\hline Group-VII & & $\begin{array}{c}100 \mathrm{mg} / \mathrm{kg}, \\
\text { i.p }\end{array}$ & $0.0 \pm 0.0 \mathrm{~ns}$ & $0.34 \pm 0.13^{* *}$ & $0.66 \pm 0.58 * * *$ & $0.86 \pm 0.48^{* * *}$ & $0.86 \pm 0.48^{* * *}$ & $0.95 \pm 0.44^{* * *}$ & $1.33 \pm 0.46 * *$ \\
\hline Group-VIII & & $\begin{array}{c}150 \mathrm{mg} / \mathrm{kg} \text {, } \\
\text { i.p }\end{array}$ & $0.0 \pm 0.0 \mathrm{~ns}$ & $0.0 \pm 0.0 * * *$ & $0.0 \pm 0.0^{* * *}$ & $0.0 \pm 0.0 * * *$ & $0.19 \pm 0.21^{* * *}$ & $0.21 \pm 0.19^{* * *}$ & $0.27 \pm 0.15^{* * *}$ \\
\hline
\end{tabular}

Values are expressed as mean \pm S.E.M. $(\mathrm{n}=6)$. Values are statistically significant at ${ }^{* * *} \mathrm{P}<0.001,{ }^{* *} \mathrm{P}<0.01,{ }^{*} \mathrm{P}<0.05, \mathrm{~ns}>0.05$ vs. control group respectively (One-way ANOVA followed by Tukey's post hoc test).

\section{Preparation of extract}

The leaves were dried in shade and stored at $25^{\circ} \mathrm{C}$. powdered, passed through sieve no. 40. The dried powdered leaves of TD $(500 \mathrm{~g})$ were first defatted with Petroleum Ether $\left(60-80^{\circ} \mathrm{C}\right)$ and later extracted with ethanol and distilled water separately by maceration for 5 days. After completion of the extraction, the solvent was removed by distillation and concentrated in vaccuo $\left(40^{\circ} \mathrm{C}\right)$ to yield ethanolic and aqueous extract respectively.

\section{Preliminary phytochemical screening of TD}

The preliminary phytochemical investigation was carried out with ethanolic and aqueous extracts of leaves of $T$. divaricata for qualitative identification of phytochemical constituents. Phytochemical tests were carried out by standard methods (Khandelwal, 2006; Kokate, 1994).

\section{Animals}

Male wistar rats weighing $200 \pm 20 \mathrm{~g}$ were provided by the animal house of TIT Pharmacy, Bhopal, from the stock originally purchased from, National Institute of Nutrition, Hyderabad, India. Animals were made available with the standard animal feed and water supply ad libitum before the experiments. The animal studies were approved by the Institutional Animal Ethics Committee (Reg. no. 831/bc/04/CPCSEA), New Delhi, India. For each experimental study rats were starved for $18 \mathrm{~h}$ with access to water only.

\section{Drug and chemicals}

Levodopa was obtained from Sun Pharma, and Haloperidol was procured from RVG Life Sciences Ltd.

\section{Acute toxicity study}

Acute toxicity study was carried out for the extracts of TD following Organization of economic co-operation and development (OECD) guidelines (OECD guideline, 2001). The extract was dissolved in distilled water in a dose of 2 $\mathrm{g} / \mathrm{kg}$ body weight and orally administered to overnightfasted, healthy rats $(n=6)$.The animals were observed continuously for $24 \mathrm{~h}$ for mortality.

\section{Catalepsy bar test}

The method described by Pemminati et al. (2007), was followed for the anticataleptic activity. The animals were divided into eight groups $(n=6)$. Group I served as Control
(Haloperidol $1 \mathrm{mg} / \mathrm{kg}$, i.p.), Group II as Standard (Levodopa $30 \mathrm{mg} / \mathrm{kg}$ i.p.), Group III-V served as the test group treated with aqueous extract (50, 100, $150 \mathrm{mg} / \mathrm{kg}$, i.p., respectively) and Group VI-VIII treated with ethanolic extract (50, 100, $150 \mathrm{mg} / \mathrm{kg}$, i.p. respectively). Standard bar test was used to measure the catalepsy. Catalepsy was induced by Haloperidol $(1.0 \mathrm{mg} / \mathrm{kg}$ i.p. $)$ and examine at every 15 minutes interval for 90 minutes. The duration for which the rat retains the forepaws extended and resting on the elevated bar $(4 \mathrm{~cm}$ high and $1 \mathrm{~cm}$ diameter) was considered as cataleptic score. The end point of catalepsy was considered when forepaws of the rat were removed from the bar or the rat moved its head in an exploratory manner. A cut-off time of 5 minutes was applied. All observations were made between 10.00 to $16.00 \mathrm{hrs}$ in a quiet room at room temperature.

\section{Statistical analysis}

The results are expressed as mean \pm S.E.M. Data were analyzed using one-way analysis of variance (ANOVA) after Tukey's multiple comparison tests. $\mathrm{P}<0.05$ was considered statistically significant in all the cases.

\section{RESULTS}

Preliminary phytochemical screening of TD

Phytochemical screening of TD revealed the presence of alkaloids, tannins, resins, proteins, amino acids, flavonoids, saponins, phenols, glycosides, steroids, triterpenoids, fixed oils and fats.

\section{Catalepsy bar test}

The cataleptic score was significantly reduced after 15 min, with all drugs viz. the standard drug Levodopa (30 $\mathrm{mg} / \mathrm{kg}$, i.p.), the aqueous extract of TD (50-150 mg/kg, i.p.) and the ethanolic extract of TD (50-150 mg/kg, i.p.). Ethanolic extract of TD significantly reduce the cataleptic score in a dose dependent manner. The reduction in cataleptic scores with ethanolic extract of TD at a dose of $150 \mathrm{mg} / \mathrm{kg}$, i.p. was significant $(\mathrm{P}<0.001)$ throughout the period of observations, except for 0 minutes. Both the extracts of TD viz. aqueous and ethanolic (50- $150 \mathrm{mg} / \mathrm{kg}$, i.p) reduce cataleptic score significantly at $90 \mathrm{~min}$. ( $\mathrm{P}<$ 0.001 ). 


\section{DISCUSSION}

In catalepsy we observe a failure to correct an externally imposed posture which is a measure of akinesia and can be evaluate using the bar test (Hubbard and Trugman, 1993). Postsynaptic striatal dopamine D1 and D2 receptors are blocked in case of a typical neuroleptic induced catalepsy (Sanberg, 1980; Farde et al., 1992).

Despite the above evidence, role of several other neurotransmitters such as acetylcholine, GABA and serotonin, have also been phenomenon (Klemm, 1985; Somani et al., 1999). Along with dysfunction of various neurotransmitters in haloperidol induced catalepsy, involvement of reactive oxygen species has also been suggested by many clinical and preclinical studies (Polydoro et al., 2004; Sagara, 1998). The neuroleptic agents induce catalepsy by inhibiting dopamine D2 receptors in the substantia nigra (Ossowska et al., 1990). Haloperidol block dopamine receptors present in the striatum and nucleus accumbens thus induce catalepsy.

Pathology of haloperidol induced catalepsy underlying increased oxidative stress. Tabernaemontana divaricata have anti- oxidative effects (Surya et al., 2011), thus keeping the above facts in mind the present study was done to evaluate the anti-cataleptic effect of Tabernaemontana divaricata in haloperidol induced cataleptic rats.

In the present study, Haloperidol $(1.0 \mathrm{mg} / \mathrm{kg}$, i.p.) induced significant catalepsy in rats which is been apparent by a considerable augmentation of time spent on the bar as compared to the control group. Above study revealed that, both the extracts viz.; aqueous and ethanolic extract of TD protect rats from catalepsy as compared to the standard drug, Levodopa.

In the above study we observed that the various extracts reduce duration of catalepsy in rats. Phytochemical screening of TD revealed the presence of alkaloids, tannis, resins, proteins, amino acids, flavonoids, saponins, phenols, glycosides, steroids, triterpenoids, fixed oils and fats. Both the extracts of TD viz. aqueous and ethanolic (50- $150 \mathrm{mg} / \mathrm{kg}$, i.p) reduce cataleptic score significantly at $90 \mathrm{~min}$. $(\mathrm{P}<0.001)$. The activities at a dose of $50-150$ $\mathrm{mg} / \mathrm{kg}$ i.p. are comparable with that of standard levodopa.

\section{CONCLUSION}

Our findings confirm the anticataleptic activity of both aqueous and ethanolic extracts of Tabernaemontana divaricata. From the study it may be concluded that the test drug can safely be replaced as an alternative agent in preventing and treating the extrapyramidal side effects of antipsychotic agents in clinical practice.

\section{ACKNOWLEDGEMENT}

The authors would like to thank the management of TIT group of institution, Bhopal and Karpagam University, Coimbatore for providing necessary facilities to carry out study.

\section{REFERENCES}

Antony, A., Biswajit, Pal, Aditya, S., Rakesh, V., Mehul, G., Ankit, P. and Sindhura, G. (2010). Anti-anxiety, anti-depressant and anti- cataleptic activity of 4-hydroxy-3-[2-(3-nitrophenyl)-2, 3-dihydro-1, 5- benzothiazepin-4-yl]-2h-chromen-2-one.Pharmacologyonline, 3: 470-478.

Farde, L., Nordstrom, A.L., Wiesel, F.A., Pauli, S., Halldin, C. and SedvallG. (1992). Positron emission tomographic analysis of central D1 and D2 dopamine receptor occupancy in patients treated with classical neuroleptics and clozapine Relation to extrapyramidal side effects. Arch Gen Psychiatry, 49: 538-44. [DOI]

Hubbard, C.A. and Trugman, J.M.( 1993). Reversal of reserpine-induced catalepsy by selective D1 and D2 dopamine agonists. Mov Disord, 8(4): 473-478. [DOI]

Kedar, N.P. (2003). Can we prevent Parkinson's and Alzheimer's disease? J Postgrad Med, 49: 236-45. PMid:14597787

Khandelwal, K.R. (2006). Practical Pharmacognosy. Nirali Prakashan publisher, Pune, 6th ed. pp 15-23.

Klemm, W.R. (1985). Evidence for a cholinergic role in haloperidol induced catalepsy. Psychopharmacology (Berl), 85: 139-42. [DOI]

Kokate, CK. (1994). Practical Pharmacognosy. Vallabh Prakashan Publisher, New Delhi, 4th ed., pp. 110-116.

Kulkarni, S.K. and Naidu, P.S. (2001). Tardive dyskinesia: An update. Drugs of Today, 37:97-119.

Leeuwenberg, A.J.M. (1991). A revision of Tabernaemontana. The old world species. Part I, Royal Botanic Gardens, kew: whitstabee litho Ltd., Whitstable, UK.

Mahdik, S.P. and Mukherjee, S. (1996). Free radical pathology and antioxidant defense in schizopherenia: a review. Schizophr Res, 19:1-17. [DOI]

Marie-Louise, G.W., Soliman, A., Vander Spek, S.C. and Kapur, S. (2001) Dopamine D2 receptor occupancy is a common mechanism underlying animal models of antipsychotics and their clinical effects. Neuropsychopharmacology, 25: 633-41. [DOI]

OECD Guidelines - "Guidance document on acute oral toxicity testing" (2001) series on testing and assessment no. 24, Organisation for economic co-operation and development, OECD environment, health and safety publications, Paris. (www.oecd.org/ehs) accessed on 12th January 2007.

Ossowska, K., Karcz, M. and Wardas, J. (1990). Straiatal and nucleus accumbens D1/D2 dopamine receptors in neuroleptic catalepsy. Eur J Pharmac, 182:327-334. [DOI]

Pemminati, S., Nair, V., Dorababu, P., Gopalakrishna, H.N. and Pai, M.R.S.M (2007). Effect of ethanolic leaf extract of Ocimum sanctum on haloperidolinduced catalepsy in albino mice. Indian J Pharmacol: 39(2): 87-89. [DOI]

Polydoro, M., Schröder, N., Lima, M.N.M., Caldana, F., Laranja, D.C. and Bromberg, E. (2004). Haloperidol and clozapine-induced oxidative stress in the rat brain. Pharmacol Biodhem Behav, 78: 751-6. [DOI]

Sagara, Y. (1998). Induction of reactive oxygen species in neurons by haloperidol. J Neurochem, 71: 1002-12. [DOI]

Sanberg, P.R., Bansey, M.D., Giordano, M. and Norman, A.B. (1988).The catalepsy test: its ups and downs, Behav Neurosci, 102: 748-59. [DOI]

Sanberg, P.R. (1980). Haloperidol-induced catalepsy is mediated by postsynaptic dopamine receptors. Nature, 284:472-3. [DOI]

Seeman, P., Corbett, R., Nam, D. and Van Tol, H. H. (1996). Dopamine and serotonin receptors: Amino acid sequences, and their clinical roles in neuroleptic Parkinsonism. Jpn J Pharmacol, 71: 187-204. [DOI]

Shivakumar, B.R. and Ravindranath, V. (1992). Oxidative stress and induced by administration of the Neuroleptics drug haloperidol attenuated by higher doses of haloperidol. Brain Researd, 595:256-62. [DOI]

Shivakumar, B.R. and Ravindranath, V. (1993). Oxidative stress and thiol modification which was induced by chronic haloperidol administration. J Pharmacol Exp Ther. 265:1137-41. PMid:8509999

Silva, S.R., Futuro, N.H.A. and Pires, J.G.P. (1995). Effect of 5-HT3 receptor antagonists on neuroleptic-induced catalepsy in mice. Europharmacology, 34: 97-9. [DOI]

Somani, R.S., Kasture, V.S. and Kasture, S.B. (1999). Haloperidol inhibits (-) bicuculline-induced seizures and bicuculline potentiates haloperidolinduced catalepsy in mice. Indian J Pharmacol, 31: 434-6.

Surya, S., Poornima, K., Ravikumar, G., Kalaiselvi, M. G., Gopalakrishnan, V. K. and Uma C., (2011). In-vitro antioxidant activity and phytochemical screening of ehanolic extract of Tabernaemontana coronaria (L.), Pharmacologyonline, 2: 212-218.

Van Beek, T.A., Verpoorte, R., Svendsen, A.B., Leeuwenberg, A.J. and Bisset, N.G. (1984). Tabernaemontana L. (Apocynaceae): a review of its taxonomy, phytochemistry, ethnobotany and pharmacology. J Ethnopharmacol, 10: 1-156. [DOI] 